\title{
Short Oligonucleotide Mass Analysis
}

National Cancer Institute

\section{Source}

National Cancer Institute. Short Oligonucleotide Mass Analysis. NCI Thesaurus. Code C19826.

A method to produce defined small DNA fragments from PCR products for analysis of DNA variations by mass spectrometry. (from 7th SPORE Investigators' Workshop) 